\title{
Article
}

\section{Changes of renin-angiotensin system- related aminopeptidases in early stage Alzheimer's disease}

Gard, Paul Richard, Fidalgo, Sara, Lotter, Isabelle, Richardson, Cassandra, Farina, Nicholas, Rusted, Jennifer and Tabet, Naji

Available at http://clok.uclan.ac.uk/16856/

Gard, Paul Richard, Fidalgo, Sara, Lotter, Isabelle, Richardson, Cassandra ORCID: 0000-0003-1208-6588, Farina, Nicholas, Rusted, Jennifer and Tabet, Naji (2017) Changes of renin-angiotensin system-related aminopeptidases in early stage Alzheimer's disease. Experimental Gerontology, 89 . pp. 1-7. ISSN 0531-5565

It is advisable to refer to the publisher's version if you intend to cite from the work. http://dx.doi.org/10.1016/j.exger.2017.01.006

For more information about UCLan's research in this area go to http://www.uclan.ac.uk/researchgroups/ and search for <name of research Group>.

For information about Research generally at UCLan please go to http://www.uclan.ac.uk/research/

All outputs in CLoK are protected by Intellectual Property Rights law, including Copyright law. Copyright, IPR and Moral Rights for the works on this site are retained by the individual authors and/or other copyright owners. Terms and conditions for use of this material are defined in the policies page.

\section{CLoK}

Central Lancashire online Knowledge www.clok.uclan.ac.uk

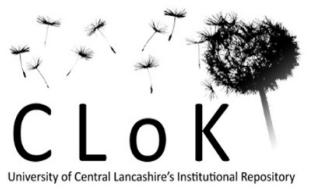


Changes of renin-angiotensin system-related aminopeptidases in early stage Alzheimer's disease.

Paul Richard Gard ${ }^{a}$, Sara Fidalgo ${ }^{a}$, Isabelle Lotter ${ }^{b}$, Cassandra Richardsonc, Nicolas Farina ${ }^{d}$, Jennifer Rusted ${ }^{\mathrm{e}}$. Naji Tabet ${ }^{\mathrm{d}}$.

a School of Pharmacy and Biomolecular Sciences, University of Brighton, Brighton, U.K.

${ }^{b}$ Department of Pharmaceutical Sciences, University of Basel, Basel, Switzerland

'School of Psychology, University of Central Lancashire, Preston, U.K.

${ }^{d}$ Brighton and Sussex Medical School, Brighton, U.K.

e School of Psychology, University of Sussex, Brighton, U.K.

Corresponding author:

Paul R Gard

School of Pharmacy and Biomolecular Sciences

University of Brighton

Moulsecoomb

Brighton, UK. BN2 4GJ

p.r.gard@brighton.ac.uk

+441273642084 


\begin{abstract}
Activities of aminopeptidases $A, B$, and N (ApA, $A p B \& A p N)$ and insulin-regulated aminopeptidase (IRAP) have been seen to be decreased amongst patients with Alzheimer's disease $(A D)$. All of these enzymes are involved with the brain renin-angiotensin system which is believed to be involved with learning and memory. This study aimed to explore the time course and the mechanisms underlying these changes.

Serum samples were collected from 45 AD patients at the start of the study, and again 13 months later $(n=37)$. The control group was 22 healthy, older, adults. Enzyme activity was determined at two substrate concentrations to allow Michaelis-Menten analysis of the enzyme activity.

The results indicated that there was decreased activity of $A p A, A p B$ and $A p N$ amongst $A D$ patients but no difference in serum IRAP activity. There were no associations between enzyme activity and age, gender nor scores on psychomotor tests.

Consideration of the data for the two time points for $A D$ patients showed that the changes in ApB occurred at an early stage of the disease and persisted, whilst those of ApA and ApN only became apparent at later stages of the disease. Although differences in MichaelisMenten parameters were not statistically significant, consideration of the values suggested that the decrease in ApB activity may be a result of changes in enzyme protein conformation, whilst that of $\mathrm{ApN}$ may be a consequence of decreased enzyme expression. Importantly, the different time courses of the effects and the differential changes in enzyme affinity and expression indicated that the observed changes with progression of AD were not a 'class effect' for serum aminopeptidases but were idiosyncratic for the individual enzymes.
\end{abstract}

\title{
Highlights
}

- Decreased serum aminopeptidases A, B and N activity in Alzheimer's disease.

- Persistent decrease in activity of aminopeptidase B from early stage of disease.

- Decreased activity of aminopeptidase $\mathrm{A}$ and $\mathrm{N}$ only in later stage of the disease.

\section{Keywords}

Renin-angiotensin system

Alzheimer's disease

Aminopeptidase A

Aminopeptidase B

Aminopeptidase $\mathrm{N}$

Insulin-regulated aminopeptidase 


\section{Introduction}

Aminopeptidases are a group of enzymes typically involved in proteolytic processing of precursors to produce biologically active neuropeptides and hormones, or conversely in the processing of biologically active molecules to produce inactive metabolites or metabolites of different activity. In tissues such as the brain, the enzymes are commonly found anchored within the cell membrane, but they may be endocytosed and found within the cytoplasm; free enzyme is also found in blood. The enzymes of current interest are aminopeptidases $A$, $\mathrm{B}$ and $\mathrm{N}$ and insulin-regulated aminopeptidase (IRAP), all of which are involved in the synthesis, metabolism or actions of the brain renin-angiotensin system (RAS, see fig. 1).

\section{Angiotensinogen}

Asp-Arg-Val-Tyr-lle-His-Pro-Phe-His-Leu-Val-lle-His-+ 440 amino acids
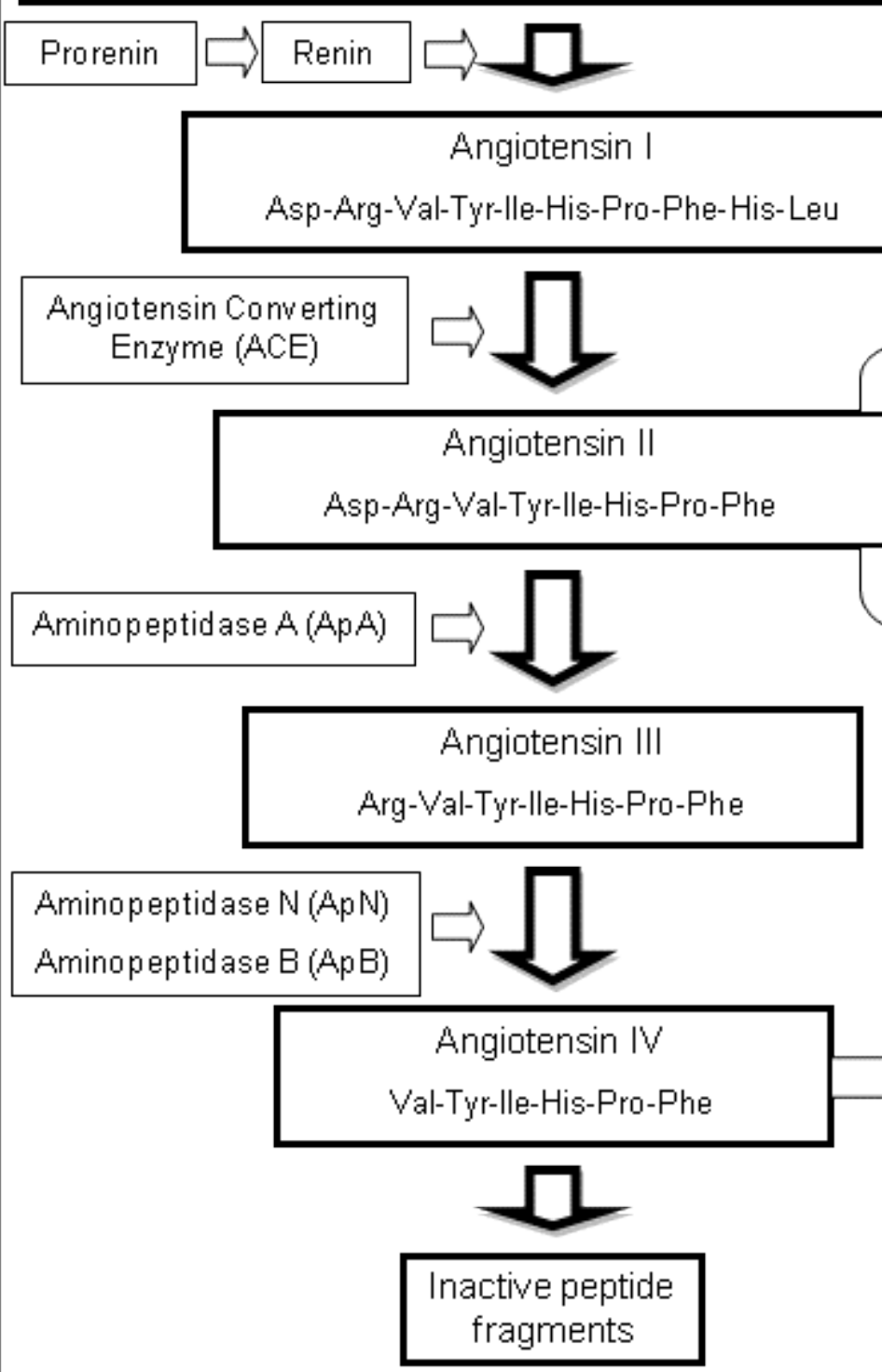
Fig. 1: A schematic representation of the renin angiotensin system illustrating the roles of aminopeptidases $A$, $\mathrm{B}$ and $\mathrm{N}$ in the synthesis and metabolism of the angiotensins and the role of insulin-regulated aminopeptidase (IRAP) as a target for angiotensin IV. (Adapted from Gard et al., 2011).

The brain RAS is known to influence, among other things, learning and memory (Gard, 2002; Mechail et al., 2011), hence its interest in conditions associated with learning deficits. The literature, reviewed in Gard (2002), reports a complex relationship with angiotensin II seen to both enhance and diminish learning and memory in animal models, depending when the animals were tested after administration of the angiotensin II. Angiotensin IV consistently improves learning and memory in animal models (eg Golding et al., 2010) and it is the metabolism of angiotensin II to angiotensin IV that probably underlies the observed beneficial effects of angiotensin II (Braszko et al., 2006). Clinically, drugs which decrease angiotensin II activity such as angiotensin converting enzyme (ACE) inhibitors and angiotensin receptor antagonists, are associated with improved cognition (Nelson et al., 2013), but whether this observed effect is associated with increased activity of angiotensin IV remains to be determined. The aim of this study was to explore further the possible association between the cognitive impairment of Alzheimer's disease and angiotensin IV activity through a detailed profile of the activities of enzymes associated with angiotensin synthesis and action.

Kuda et al., (1997) reported that the activity of aminopeptidase A (ApA) but not aminopeptidase $B(A p B)$ nor aminopeptidase $N(A p N)$ was decreased in plasma from patients with Alzheimer's disease (AD). More recently Puertas et al (2013) reported that the activities of plasma ApA, ApB, ApN and IRAP were decreased in patients with early stage Alzheimer's disease (AD) compared to healthy, age-matched controls. The changes in ApA activity were seen in male patients only and there was no difference in the activity of aspartyl aminopeptidase between patients and controls. In this recent study enzyme activity of $A p A, A p B, A p N$ and IRAP was determined by cleavage of the artificial substrates glutamyl-ß-naphthylamide, arginyl-ß-naphthylamide, alanyl-ß-naphthylamide and leucyl-ßnaphthylamide respectively, using a single $100 \mu \mathrm{M}$ concentration of substrate. The Kuda study utilised a single $3 \mathrm{mM}$ concentration of nitoaniline-based artificial substrates (see later). Whilst use of a single concentration of substrate approximate to that which elicits $50 \%$ of the maximal enzyme activity ( $\mathrm{K}_{\mathrm{M}}$, Michaelis-Menten constant) allows demonstration of reduced enzyme activity, it does not allow interrogation of the possible mechanism underlying the reduction. The aim of this study was to use multiple concentrations of substrate to allow further dissection as to whether the previously-reported reduction in activity was due to a change in enzyme affinity for the substrate $\left(\mathrm{K}_{\mathrm{M}}\right)$ or a change in expression of the enzyme $\left(V_{\max }\right)$.

The current study measured serum activity of $A p A, A p B, A p N$ and IRAP using two concentrations of the artificial substrates L-glutamyl- $p$-nitroanilide; L-arginyl- $p$-nitroanilide; L-alanine- $p$-nitroanilide and L-leucine- $p$-nitroanilide in a healthy control group and in a group of patients with mild to moderate AD who were sampled twice 13 months apart in order to assess changes with disease progression.

\section{Methods}

Approval for the study was provided by the Brighton and Sussex National Health Service (NHS) Research Ethics Committee, the National Research Ethics Service Committee, London, 
and the Research and Development Committee of Sussex Partnership NHS Foundation Trust. Written informed consent was obtained from all participants with capacity to do so; carers provided assent for those that lacked capacity and showed no dissent to the research.

\subsection{Participants}

Participants were recruited via memory clinics in East Sussex, Southern England. Demographic and psychometric data and blood were collected from 45 individuals (67-91 $\mathrm{yrs}$ ) at the start of the study. Blood samples were obtained from 37 of those individuals $\underline{13}$ months later. All patients included in the study were clinically diagnosed with mild to moderate $A D$ according to the National Institute of Neurological and Communicative Disorders and Stroke and the Alzheimer's Disease and Related Disorders Association criteria (McKhann et al., 2011).

A control group of 26 individuals (65-90 yrs) was recruited from the University of the Third Age and the St John's Day Centre and Café in Brighton and Hove, Southern England. Participants had no memory complaints and no diagnosis of a dementia. Blood samples were obtained from 24 of this group and demographic and psychometric parameters obtained from 22.

Exclusion criteria for the control group included smokers, individuals taking antiinflammatory medications, those with autoimmune or rheumatological disorders, acute or chronic inflammatory conditions, clinically-obvious infections or receiving chemotherapy. No exclusion criteria were applied to either the control group or the patients with respect to either treated or untreated hypertension or heart failure.

\subsection{Psychometric Assessments.}

\subsubsection{Addenbrooke Cognitive Examination-Revised (ACE-R).}

All participants completed the ACE-R, a 100-point assessment of memory, verbal fluency, visuospatial abilities, language, attention and orientation in which components of the MiniMental State Examination (MMSE) are embedded. The normal total score for the age range 70-75 is 84 (Mioshi et al., 2006).

\subsubsection{Trail Making Test.}

All participants completed the Trail-Making test, a two part test in which 25 numbered circles are randomly arranged and individuals are required to draw lines between the circles in ascending order (Part A). Part B comprises a page of randomly positioned circles containing two sequences: one of letters ( $A$ to $L$ ) and one of numbers (1-13). Individuals are required to connect the circles by drawing lines alternating between numbers and letters in sequential order. The time taken to correctly complete parts $A$ and $B$ was recorded.

\subsection{Study samples and analysis}

Blood samples were collected in the afternoon from all participants at the time of cognitive assessment. Clotted samples were centrifuged at $10,000 \mathrm{~g}$, and serum was 
collected and stored at $-80^{\circ} \mathrm{C}$ until assay. The method selected for determination of enzyme activity was similar to that of Kuda et al (1997) where the product of enzymatic cleavage is p-nitroaniline rather than the method used by Puertas et al (2003) where the product is naphthylamine, which is carcinogenic. ApA activity was assessed as the ability of serum to cleave L-glutamyl-p-nitroanilide; ApB activity was assessed as the ability of serum to cleave L-arginyl-p-nitroanilide; ApN activity was assessed as the ability of serum to cleave L-alanine- $p$-nitroanilide and IRAP activity was assessed as the ability of serum to cleave Lleucine- $p$-nitroanilide. Briefly, $20 \mu \mathrm{l}$ serum were incubated with $180 \mu \mathrm{l}$ of 1.5 or $3.0 \mathrm{mM}$ substrate in Tris buffer $(0.05 \mathrm{M}$ Tris, $0.14 \mathrm{M} \mathrm{NaCl}, \mathrm{pH} 7.4)$ for 90 minutes at $37^{\circ} \mathrm{C}$. Absorbance was measured every 10 minutes at $405 \mathrm{~nm}$. Absorbance values were converted to nitroaniline (product) concentrations by reference to a standard curve and results expressed as rate of product formation ( $\mathrm{mMol} / \mathrm{min}$ ). In a sub-set of samples, controls and 13 month $A D$, plasma protein concentrations were determined using the method of Bradford (1976) allowing enzyme activity to be expressed as $\mathrm{mMol} / \mathrm{min} / \mathrm{mg}$ protein.

\subsection{Data analysis}

Non-linear regression of rate of product formation versus substrate concentration (mM) using GraphPad Prism software allowed estimation ( \pm standard error) of Michaelis-Menten parameters: maximal rate of product formation $\left(V_{\max }\right)$ and substrate concentration at $50 \%$ maximal rate of product formation ( $\mathrm{K}_{\mathrm{M}}$, Michaelis-Menten constant).

Demographic and psychometric data are presented as means \pm standard deviation and differences between groups were assessed using one-way ANOVA followed by Dunnett's or Tukey's tests as appropriate or Student's independent t-test. Categorical variables were compared using the Chi-squared test. Differences in enzyme parameters between demographic/ diagnostic groups were determined using Student's independent t-test, differences between time points within individuals were assessed using a paired t-test. Correlations between enzyme parameters (rate of product formation at a substrate concentration of 1.5 and $3 \mathrm{mM}$ ) and demographic and psychometric data were assessed using Pearson's product-moment correlation. Statistically significant differences / correlations were determined when $\mathrm{p}<0.05$ (two-tailed).

\section{Results}

The age range of the patients at recruitment (66-90 yrs) was similar to that of the controls (65-90 yrs), but as demonstrated in table 1, the mean age of the control group was significantly younger, by approximately 6 years, than that of the patient group (Student's ttest, $p<0.002$ ). There was no significant difference in the gender ratio between the patient group and control group (Chi-squared). MMSE scores (derived from the ACE-R) were significantly lower in the patient group than the control group (ANOVA, $p<0.001$ ) and there was a significant decline within the patient group over the 13 months of the study (Paired $t-$ test, $p=0.003$ ). For ACE-R scores, there was a similar significant difference between the control volunteers and the patients (ANOVA, $p<0.001$ ) and considering data for those individuals for which ACE-R scores were available at both time points, ACE-R scores declined significantly over the 13 months of the study indicated by a mean decrease in score of 3.38 points (Paired t-test, $p=0.011$ ). 
In the Trail Making test, there were significant increases in times taken to complete parts $A$ and $B$ of the test over the 13 month study period (Paired t-test, $p=0.012$ and $<0.001$ respectively).

Table 1: Demographic and psychometric characteristics of participants. $* * *$ indicates significant difference from control, $\mathrm{P}<0.005 .+,+\dagger$ and $+\dagger+$ indicate significant difference between patients at recruitment and 13 months later, $p<0.05,0.01$ and 0.005 respectively.

\begin{tabular}{|lccc|}
\hline & $\begin{array}{c}\text { Controls } \\
(\mathrm{n}=22)\end{array}$ & $\begin{array}{c}\text { Patients }(\mathrm{t}=0) \\
(\mathrm{n}=45)\end{array}$ & $\begin{array}{c}\text { Patients }(\mathrm{t}=12 \text { months }) \\
(\mathrm{n}=45)\end{array}$ \\
\hline Age $($ years \pm SD) & $75.1 \pm 7.9$ & $81.5 \pm 6.0 * * *$ & $82.6 \pm 6.0$ \\
Male:Female & $6: 16$ & $22: 23$ & $22: 23$ \\
MMSE score $( \pm S D)$ & $29.2 \pm 0.7$ & $24.5 \pm 2.8 * * *$ & $23.0 \pm 4.6+\dagger$ \\
ACER-R score $( \pm S D)$ & $94.7 \pm 3.7$ & $69.8 \pm 9.9 * * *$ & $67.3 \pm 13.1+$ \\
Trails A score $( \pm S D)$ & - & $65 \pm 48$ & $180 \pm 302+$ \\
Trails B score $( \pm S D)$ & - & $215 \pm 135$ & $531 \pm 433++\dagger$ \\
\hline
\end{tabular}

Within the samples obtained from the control individuals, activity of none of the enzymes studied, at a substrate concentration of $3 \mathrm{mM}$, differed between males and females. Importantly, see later, there was no gender difference in total serum protein concentration within the control individuals. Inclusion of data from the patient group to increase the sample size did not reveal any significant gender difference in activity of any of the enzymes.

Similarly there were no statistically significant relationships between age and enzyme activity at $3 \mathrm{mM}$ substrate for any of the enzymes studied either within the control group $\left(R^{2}=0.005-0.085\right.$, Pearson's Product-Moment correlation) or within the combined control and patient groups ( $R^{2}=0.007-0.025$, Pearson's Product-Moment correlation).

Analysis of the enzyme activity, expressed as rate of product formation per unit serum volume $(20 \mu \mathrm{l})$, between the diagnostic groups revealed that ApB activity was significantly decreased in the patient group both at recruitment and after 13 months when the substrate concentration used was $1.5 \mathrm{mM}$ ( $p<0.05$ in both cases). When the substrate concentration was $3.0 \mathrm{mM}$, the reduction in ApB activity became non-significant $(p=0.2839)$. Activities of $\mathrm{ApA}$ and ApN were significantly reduced in the patient group, at the 13 month time point only, when the substrate concentration was $1.5 \mathrm{mM}(p<0.05$ in both cases, fig. 2$)$. There were no significant differences in IRAP activity between the groups. 


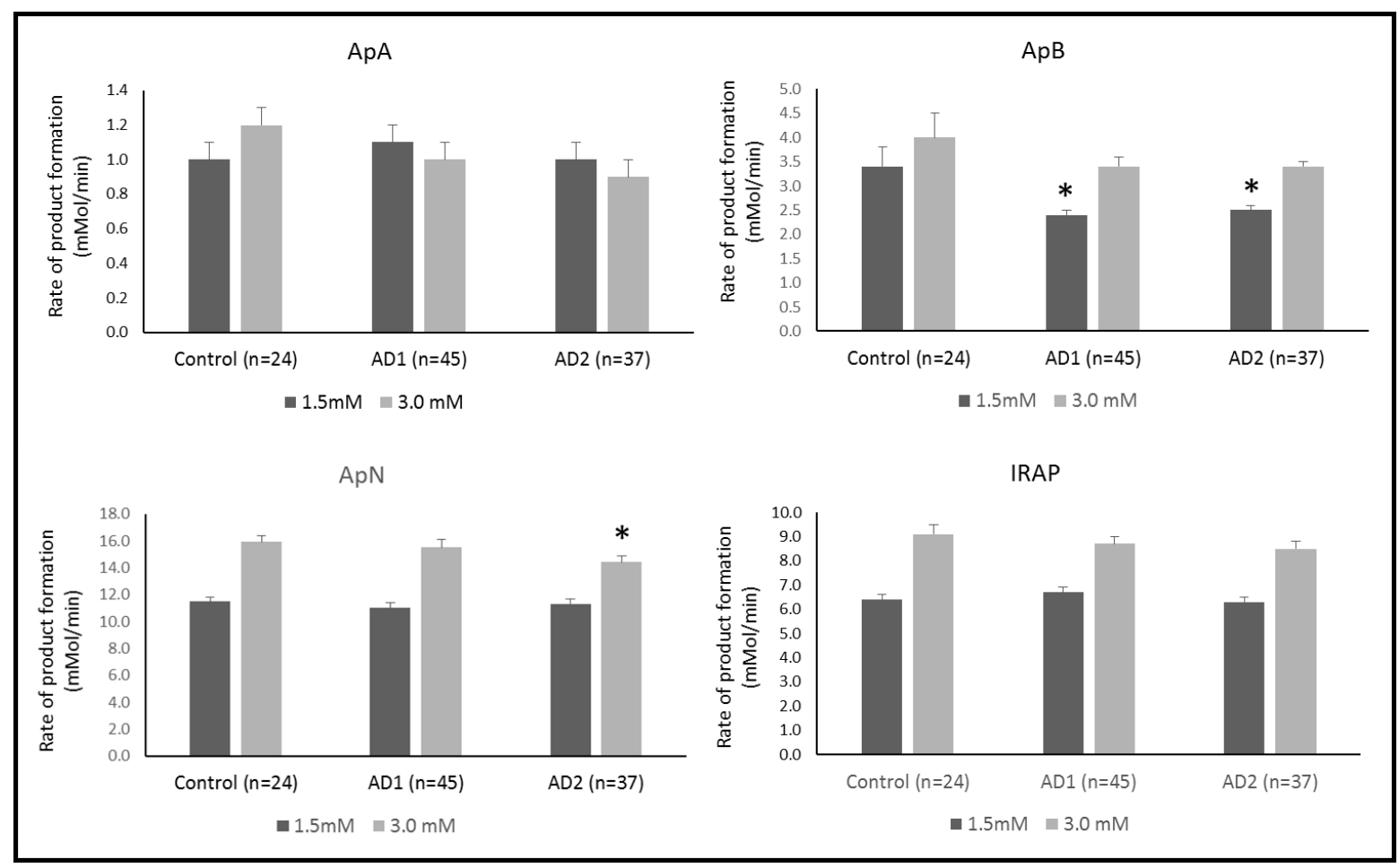

Fig. 2: Activities of the enzymes $A p A, A p B, A p N$ and IRAP as determined as the mean rate ( \pm sem) of product formation from L-glutamyl-p-nitroanilide; L-arginyl-p-nitroanilide; L-alanine-p-nitroanilide and L-leucine-pnitroanilide respectively at substrate concentrations of 1.5 and $3.0 \mathrm{mM}$. AD1 and AD2 represent individuals

with Alzheimer's disease at recruitment and 13 months later. For each individual enzyme, * indicates statistically significant difference of the $A D$ values from control value at the relevant substrate concentration, $p<0.05$ (Student's independent t-test).

Serum protein concentrations were determined for the control group and the second (13 month) patient group only. Analysis of enzyme activity, determined as product formation (mMol) per minute per $\mathrm{mg}$ serum protein demonstrated that, at a substrate concentration of $1.5 \mathrm{mM}$, only ApB had significantly decreased enzyme activity in the Alzheimer's disease group $(p<0.05)$. At a substrate concentration of $3 \mathrm{mM}$, only ApA showed significantly reduced activity in the patient group ( $p<0.05$, fig. 3 ). 


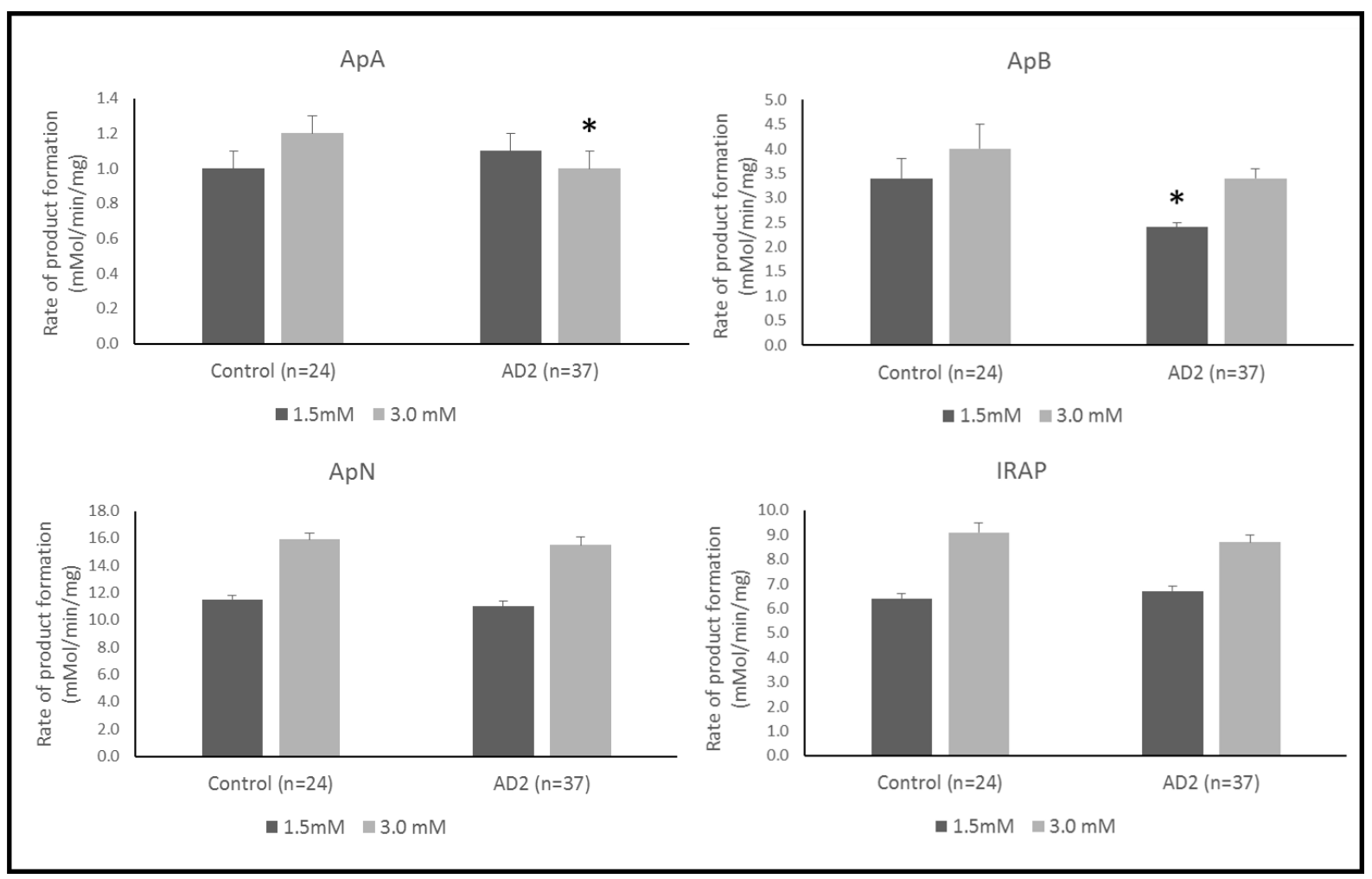

Fig. 3: Activities of the enzymes $A p A, A p B, A p N$ and IRAP as determined as the mean rate ( \pm sem) of product formation from L-glutamyl-p-nitroanilide; L-arginyl-p-nitroanilide; L-alanine-p-nitroanilide and L-leucine-pnitroanilide respectively at substrate concentrations of 1.5 and $3.0 \mathrm{mM}$, per $\mathrm{mg}$ serum protein. AD2 represent individuals with Alzheimer's disease 13 months after initial recruitment. For each individual enzyme, * indicates statistically significant difference of the $A D$ values from control value at the relevant substrate concentration, $\mathrm{p}<0.05$ (Student's independent t-test).

A more elegant analysis of the enzyme activity is achieved by fitting same results for the rate of product formation at different substrate concentrations to the Michaelis-Menten equation, see fig. 4 for an illustrative example based on the results for ApB displayed in fig. 2. Such analysis allows estimation of values for maximal rate of product formation $\left(V_{\max }\right)$ and the substrate concentration at $50 \% \mathrm{~V}_{\max }$ (Michaelis-Menten constant, $\mathrm{K}_{\mathrm{M}}$. 


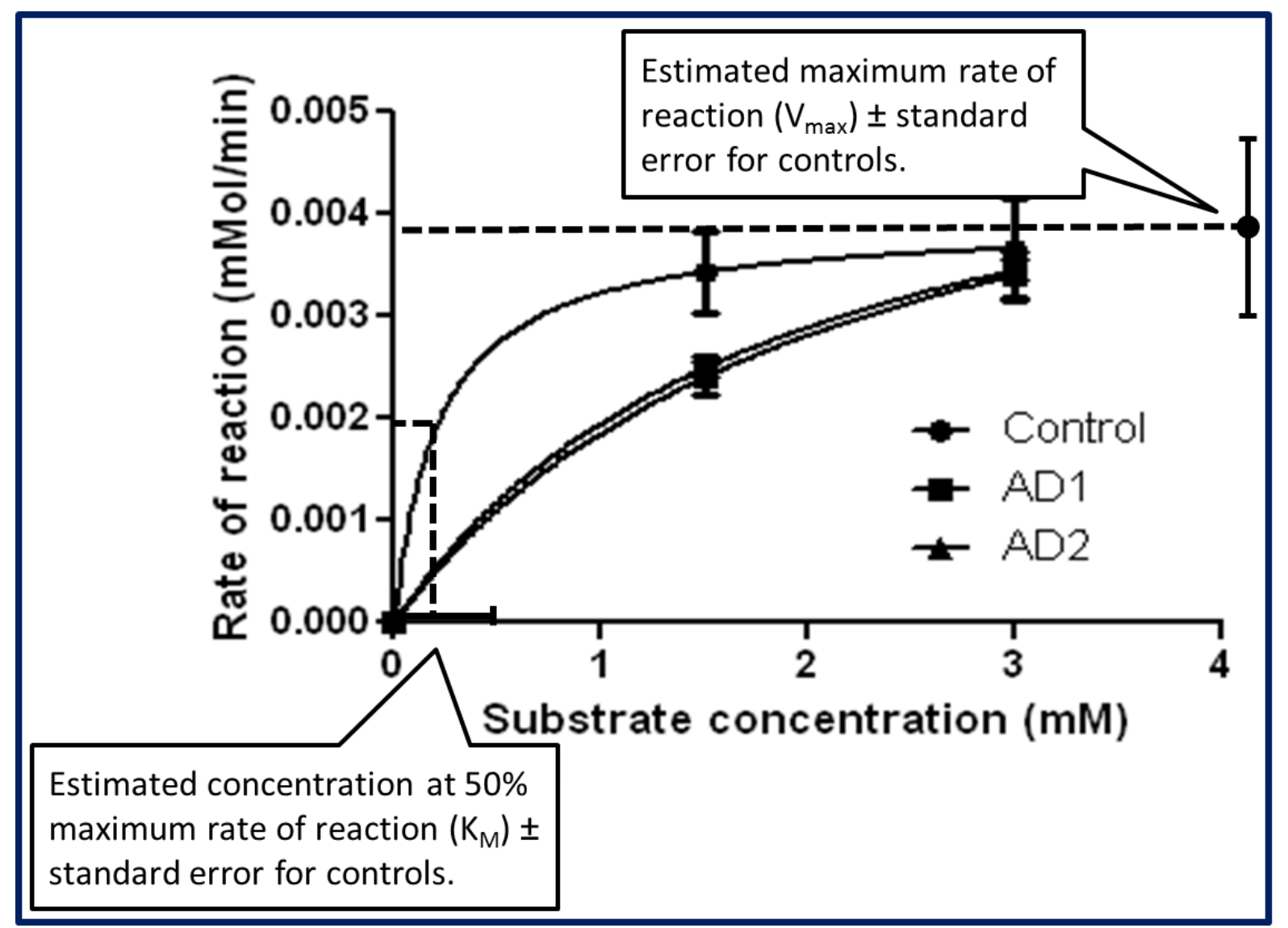

Fig. 4: Michaelis-Menten plot for aminopeptidase B based on data from fig. 2. Rate of hydrolysis of substrate (arginine-p-nitroaniline) to nitroaniline by serum samples obtained from healthy volunteers (control $n=24)$ and from patients with Alzheimer's disease at the start of the study (AD1, $n=45)$ and 13 months later ( $A D 2, n=37)$ is

plotted against substrate concentration. The figure shows the estimated maximum rate $\left(\mathrm{V}_{\max }\right) \pm$ sem for control subjects $(0.00392 \pm 0.00097 \mathrm{mMol} / \mathrm{min})$ with a substrate concentration at $50 \% \mathrm{~V}_{\max } \pm \operatorname{sem}\left(\mathrm{K}_{\mathrm{M}}\right.$, Michaelis-Menten constant) of $0.216 \pm 0.539 \mathrm{mM}$.

Table 2 gives the estimated enzyme kinetic parameters for the ApB, ApN and IRAP; changes in activity of $A p A$ with substrate concentration were such that it was not possible to estimate values for $V_{\max }$ or $K_{M}$ with any accuracy. One-way ANOVA was unable to detect any significant differences in the parameters for $\mathrm{ApB}, \mathrm{ApN}$ or IRAP between the diagnostic groups.

Table 2: Estimates of Michaelis-Menten parameters ( $\mathrm{K}_{\mathrm{M}}$ and $\mathrm{V}_{\max } \pm$ sem) for $\mathrm{ApB}, \mathrm{ApN}$ and IRAP in healthy controls and Alzheimer's disease patients on two occasions, 13 months apart.

\begin{tabular}{|l|c|c|c|c|c|c|}
\hline & \multicolumn{3}{|c|}{$K_{\mathrm{M}}(\mathrm{mM})$} & \multicolumn{3}{c|}{$\mathbf{V}_{\max }(\boldsymbol{\mu M} \mathrm{Mol} / \mathrm{min})$} \\
\hline Enzyme & $\begin{array}{c}\text { Control } \\
(\mathbf{n}=\mathbf{2 4})\end{array}$ & $\begin{array}{c}\text { AD1 } \\
(\mathbf{n}-45)\end{array}$ & $\begin{array}{c}\text { AD2 } \\
(\mathbf{n}=\mathbf{3 7})\end{array}$ & $\begin{array}{c}\text { Control } \\
(\mathbf{n = 2 4})\end{array}$ & $\begin{array}{c}\text { AD1 } \\
(\mathbf{n}-\mathbf{4 5})\end{array}$ & $\begin{array}{c}\text { AD2 } \\
(\mathbf{n}=\mathbf{3 7})\end{array}$ \\
\hline ApB & $0.216 \pm 0.539$ & $2.143 \pm 1.044$ & $1.861 \pm 0.438$ & $3.923 \pm 0.970$ & $5.829 \pm 1.365$ & $5.584 \pm 0.590$ \\
\hline ApN & $1.934 \pm 0.457$ & $2.125 \pm 0.549$ & $1.096 \pm 0.290$ & $26.220 \pm 2.834$ & $26.460 \pm 3.274$ & $19.600 \pm 1.740$ \\
\hline IRAP & $2.155 \pm 0.605$ & $1.349 \pm 2.455$ & $1.553 \pm 0.390$ & $15.550 \pm 2.104$ & $12.670 \pm 8.730$ & $12.910 \pm 1.325$ \\
\hline
\end{tabular}


Despite there being some evidence of significantly decreased aminopeptidase activity in patients with $A D$, with some changes over time / severity of the disease, there were no significant correlations between activity of any of the enzymes studied (at substrate concentrations of $3 \mathrm{mM}$ ) and neuropsychological test scores (Pearson product moment correlation).

\section{Discussion}

Puertas and colleagues (2013), and to some extent Kuda et al (1997) showed that plasma aminopeptidase activity was decreased in AD; this study sought to replicate and explore potential mechanisms underlying the observed changes. The current study identified reduced activities of $A p A, A p B$ and $A p N$ within the $A D$ population, but unlike the work of Puertas and colleagues, no difference in IRAP activity. The decreased activities identified were dependent on substrate concentration and to some extent disease severity.

There are some methodological differences between the studies which may explain our failure to fully replicate the earlier results, but fact that all three studies have identified decreased aminopeptidase activity in AD underlines the robustness of the earlier findings. The methodological differences between the current study and that of Puertas et al of greatest note are the ages of the control and patient groups, the lack of an exclusion criterion regarding hypertension, use of antihypertensive medication or treatments for heart failure (eg ACE inhibitors). Kuda et al do not state the age of the patients or controls nor any exclusion criteria. Other less important differences are the substrates used to determine enzyme activity, the use of serum rather than plasma and the decision, like Kuda et al, not to express enzyme activity per mg plasma protein.

One of the possible confounding factors between studies was the ages of the patient and control groups. In the study of Puertas et al (2013) the two groups were very closely matched, whilst in the current study the controls were approximately 6 years younger than the AD patients; Kuda et al state that the groups were age matched without giving any ages. Such an age difference in the current study may have obscured any differences in enzyme activity between the groups as there is evidence of increasing aminopeptidase activity with age (eg ljima et al., 2002); any such age-related increase in enzyme activity might explain the failure to identify reduced aminopeptidase activity the older AD patients. Although the patients of the current study were markedly older than those studied by Puertas et al (2013), by approximately 8 years, the MMSE scores (derived from ACE-R), however, were very similar, suggesting a comparable disease severity. Unlike the study of Puertas, the current study did not detect any significant relationship between enzyme activity and MMSE score, nor scores on any of the other, more sensitive, psychometric tests. MMSE is recognised as a coarse measure of cognitive ability (Votruba et al., 2016) and thus lack of any robust association with enzyme activity is not surprising. The independence of minor variabilities in scores on the other psychomotor tests and enzyme activity underlines the fact that cognitive function and plasma aminopeptidase activity are probably not precisely nor causatively associated.

The control group participants of the current study were very similar in age to those of Puertas et al. There was no significant correlation between age and enzyme activity over the short age span studied although age-related changes in the activity of ApA and aspartyl 
aminopeptidase, typically increasing activity with age, have been reported over the life-span (Martinez et al., 1998, ljima et al., 2002). Similarly the current study did not detect any gender differences in enzyme activity in the control group nor the combined control and patient group, this is at variance with Puertas and colleagues (2013) who identified a significantly lower activity of ApA in control females than control males. Martinez et al (1998) also previously reported decreased activity of ApA and aspartyl aminopeptidase in females compared to males, but only in the 16-45 and 46-65 year age groups respectively.

Hypertension and use of antihypertensive agents was not an exclusion criterion of the current study, partly because of the ubiquitous nature of the condition. Hypertension is known to be associated with increased ApA activity (Ijima et al., 2002), and any form of long-term therapy acting on the RAS might be expected to alter enzyme activity. Such lack of exclusion may explain the failure to replicate the decrease in IRAP function in the current study, but the replication of the findings of the earlier study for ApA, ApB and ApN again suggest that the earlier findings of Puertas et al can be generalised to a more heterogeneous population.

Within the literature there is some disagreement concerning the specificity of the enzymes studied, and thus the appropriate choice of substrate. In all cases, the current study utilised substrates comparable to those used by Kuda et al and Puertas and colleagues, the findings are therefore comparable. ApA is the generally recognised name for glutamyl-aminopeptidase (EC3.4.11.7) although typically it is also seen as being responsible for the conversion of angiotensin II to angiotensin III by the removal of aspartic acid, there is therefore some confusion between the activities of ApA and aspartylaminopeptidase (Mayas et al., 2001). Activity of ApA was determined by the removal of glutamic acid from glutamyl-ß-naphthylamide and glutamyl-p-nitroanilide in the earlier and current study respectively, thus there can be confidence concerning consistency of the findings.

Similarly ApN is involved in the conversion of angiotensin III to angiotensin IV by the removal of arginine. It is typically determined by cleavage of the substrates alanine- $\beta$ naphthylamide or alanine-p-nitroanilide, again indicating the lack of specificity of its actions. The use of the alanine substrate by both studies again allows confidence in the results.

Like ApN, ApB is also involved in the conversion of angiotensin III to angiotensin IV by the removal of arginine and in the two studies was determined by cleavage of arginine- $\beta$ naphthylamide or arginine-p-nitroanilide respectively.

IRAP is perhaps the most complicated of the aminopeptidases being investigated. Originally identified as oxytocinase or human placental leucine aminopeptidase (PLAP), it is known to cleave leucine and cystine moieties. It is believed to be involved with the degradation of endogenous oxytocin, vasopressin, lys-bradykinin, met-enkephalin, dynorphin $A$ and other peptide hormones, although bradykinin and met-enkaphalin contain neither leucine nor cystine, indicating its lack of specificity. IRAP has also been shown to be the active binding site for angiotensin IV (Albiston et al., 2001), with the enzyme activity being inhibited by angiotensin IV. Aminopeptidase activity was determined by cleavage of leucyl-ß-naphthylamide and leucine-p-nitroanilde in the two studies respectively.

Two other differences between the current study and that of Puertas (2013) were the use of serum rather than plasma, and the expression of enzyme activities relative to serum volume or plasma protein. Whilst for some proteins there are markedly different concentrations in serum and plasma, for example brain derived neurotrophic factor ( 240 amino acids) for which concentrations are 10-fold higher in serum than plasma (eg D'Sa et 
al., 2012), the aminopeptidases (eg ApN: 967 amino acids, IRAP: 1024 amino acids) do not appear to differ in concentration between the two fluids (eg Fylling, 1964, Riad, 1966). Total plasma protein concentrations, however, do differ between serum and plasma (Miles et al., 2004), with total protein approximately $2.5 \%$ lower in serum. Clinical chemistry results are typically reported as quantity or activity per unit volume with protein concentrations allowing some potential correction for hydration or nutritional status, but as there were no significant differences in serum protein concentration between the diagnostic groups, such correction was deemed redundant. The results indicated that when correction for serum protein concentration was applied, some of the previously identified significant differences in enzyme activity between the groups were lost. It is our belief that use of serum without correction for protein concentration is unlikely to have significantly compromised the replication of the earlier study, other than to have obscured some of the differences previously identified, possibly due to the marginal difference in protein concentration between serum and plasma.

Consideration of the rate of product formation at different substrate concentrations and estimation of Michaelis-Menten parameters gives some insight into the possible mechanisms underlying the observed decreases in enzyme activity. Estimates based on two substrate concentrations lack precision and statistical analysis of the results did not identify any significant differences between the patient groups, the results do, however, still provide some useful information. Our results indicate that activity of $A p B$ is decreased in early $A D$ and that the decreased activity persists as the disease progresses. Activities of ApA and $A p N$, on the other hand are significantly decreased only later in the disease. In the case of $A p B$, the Michaelis-Menten analysis suggests that there is an increase in $\mathrm{K}_{M}$ with little or no change in $V_{\max }$. An increase in $K_{M}$ suggests that the observed decrease in enzyme activity is a result of decreased affinity of the enzyme for its substrate (conformational change), rather than a change in the concentration of enzyme present (enzyme expression).

In the case of $\mathrm{ApN}$, the Michaelis-Menten analysis suggests no change in $\mathrm{K}_{\mathrm{M}}$ but a decrease in $V_{\max }$ later in the disease. Such a change would indicate decreased enzyme expression with no change in conformation. It was not possible to obtain any reliable estimates of $\mathrm{K}_{\mathrm{M}}$ or $\mathrm{V}_{\max }$ for $\mathrm{ApA}$, the mechanism underlying the decreased activity in later $A D$ therefore remains unresolved

In conclusion, this current study has identified decreases in the activities of $A p A, A p B$ and $A p N$, but not IRAP, in the serum of Alzheimer's disease patients. These reductions have implications for the synthesis of brain angiotensin IV and may contribute to the cognitive deficit of $A D$. The results suggest that the changes in $A p B$ occur at an earlier stage of the disease and persist, whilst those of $\mathrm{ApA}$ and $\mathrm{ApN}$ only become apparent at later stages of the disease. The decreases in $\mathrm{ApB}$ activity may be a result of changes in enzyme protein conformation, whilst those of $\mathrm{ApN}$ may be consequent to a decrease in enzyme expression. Importantly, the different time courses of the effects and the differential changes in enzyme affinity and expression indicate that the observed changes with progression of $A D$ are not a 'class effect' for serum aminopeptidases but are idiosyncratic for the individual enzymes.

These observations and conclusions could now be explored further by investigation of enzyme expression in AD patients, for example utilising mass spectroscopy, which would also inform on any changes in amino acid sequence and degree of glycosylation. Circular dichroism would determine changes in conformation of the isolated enzymes. A better understanding of these changes in enzyme activity my increase the understanding of $A D$ 
pathology and allow for the development of markers for diagnosis or monitoring of treatment efficacy.

\section{Conflict of interests}

The authors declare no conflicts of interest

\section{Acknowledgements}

This research did not receive any specific grant from funding agencies in the public, commercial, or not-for-profit sectors.

\section{References}

A. L. Albiston, S. G. McDowall, D. Matsacos., P. Sim., E. Clune., T. Mustafa., J. Lee., F. A. O. Mendelsohn., R. J. Simpson., L. M. Connolly., S. Y. Chai, 2001. Evidence that the angiotensin IV (AT(4)) receptor is the enzyme insulin-regulated aminopeptidase J. Biol. Chem. 276, 48623-48626.

M. M. Bradford, 1976. Rapid and sensitive method for the quantitation of microgram quantities of protein utilizing the principle of protein-dye binding. Anal. Biochem. 72, 248-254.

J. J. Braszko, A. Walesiuk, P. Wielgat, 2006. Cognitive effects attributed to angiotensin II may result from its conversion to angiotensin IV. J.R.A.A.S. 7, 168-174.

C. D'Sa, R. J. Dileone, G. M. Anderson, R. Sinha, 2012. Serum and plasma brain-derived neurotrophic factor (BDNF) in abstinent alcoholics and social drinkers. Alcohol 463 , 253-259.

P. Fylling, 1964. Serum and plasma leucine aminopeptidase activity during induction of labour. Scandinav. J. Clin. \& Lab. Investiation 16, 172-176.

P. R. Gard, 2002. The role of angiotensin in cognition and behaviour. Eur. J. Pharmacol. 438, 1-14

P. R. Gard, G. W. J. Olivier, B. J. Golding, C. Bourner, T. Dang, H. Haliru, E. Higgins, H. Kimberley, O. Loginova, S. Madhavi, D. Ryan, 2011. Assessment of biological activity of novel peptide analogues of angiotensin IV. J. Pharm. Pharmacol. 63, 565-571.

B. J. Golding, A. D. J. Overall, G. Brown, P. R. Gard, 2010. Strain differences in the effects of angiotensin IV on mouse cognition. Eur. J. Pharmacol. 641, 154-159

M. Ijima, S. Nomura, M. Okada, Y. Ikoma, T. Ito, T. Mitsui, O. Maeda, S. Mizutani, 2002. Effects of age, hypertension and HRT on serum aminopeptidase A activity. Maturitas 43, 215-221

T. Kuda, M. Shoji, H. Arai, S. Kawashima, T. C. Saido, 1997. Reduction of plasma glutamyl aminopeptidase activity in sporadic Alzheimer's disease. Biochem. Biophys. Res. Commun. 231, 526-530

G. M. McKhann, D. S. Knopman, H. Chertkow, B. T. Hyman, C. R. Jack Jr., C. H. Kawash, W. E. Klunk, W. J. Koroshetz, J. J. Manly, R. Mayeux, R. C. Mohs, J. C. Morris, M. N. Rossor, P. Scheltens, M. C. Carrillo, B. Thies, Sandra Weintraub, C. H. Phelps, 2011. The diagnosis of dementia due to Alzheimer's disease: Recommendations from the National 
Institute on Aging-Alzheimer's Association workgroups on diagnostic guidelines for Alzheimer's disease. Alzheimer's \& Dementia 7, 363-269.

J. M. Martinez, I. Prieto, M. J. Ramirez, M. de Gasparo, F. Hermoso, J. M. Aria, F. Alba, M. Ramirez, 1998. Sex differences and age-related changes in human serum aminopeptidase A activity. Clin. Chim. Acta. 274, 53-61.

M. D. Mayas, M. J. Ramırez-Exposito, M. J. Garcıa, M. Ramırez, J. M. Martınez-Martos, 2001. Ethanol modifies differently aspartyl- and glutamyl-aminopeptidase activities in mouse frontal cortex synaptosomes. Brain Res Bull. 57, 195-203

R. Mechaeil, M. Lewis, J. Grice, P. R. Gard, A. Jackson, J. Rusted, 2011. Angiotensin receptor antagonists as potential cognitive enhancing agents. Psychopharmacol. 217, 51-60.

R. R. Miles, R. F. Roberts, A. R. Putnam, W. L. Roberts, 2004. Comparison of serum and heparinized plasma samples for measurement of chemistry analysis. Clin. Chem. 50, 1704-1706

E. Mioshi, K. Dawson, J. Mitchell, R. Arnold, J. R. Hodges, 2006. The Addenbrooke's Cognitive Examination Revised (ACE-R): a brief cognitive test battery for dementia screening. Int. J. Geriatric Psychiatry 21, 1078-1085.

L. Nelson, C. Richardson, N. Tabet, P. R. Gard, 2013. Antihypertensives, angiotensin, glucose and Alzheimer's disease. Expert Review of Neurotherapeutics 13, 477-482

M. C. Puertas, J. M. Martinez-Martos, M. Cobo, P. Loreite, R. M. Sandalio, T. Palomeque, M. I. Torres, M. Pilar Carrera-Gonzalez, M. D. Mayas, M. J. Ramirez-Exposito, 2013. Plasma renin-angiotensin system-regulating aminopeptidase activities are modified in early stage Alzheimer's disease and show gender differences but are not related to apolipoprotein E genotype. Experimental Gerontology 48, 557-564

A. M. Riad, 1966. Changes in pregnancy serum oxytocinase activity during oxytocin infusion and their physiological significance. J. Obstet. Gynaecol. Br. Emp. 73, 977-82

K. L. Votruba, C. Persad, B. Giordani, 2016. Cognitive deficits in healthy elderly population with "normal" scores on the mini-mental state examination. J. Geriat. Psychiatry Neurol. 29, 126-132 